\title{
The role of the understory in litter DOC and nutrient leaching in boreal forests
}

\author{
Geert Hensgens (1) - Hjalmar Laudon • Matthias Peichl • Itziar Aguinaga Gil • \\ Quan Zhou • Martin Berggren
}

Received: 25 October 2019/Accepted: 16 April 2020/Published online: 4 May 2020

(C) The Author(s) 2020

\begin{abstract}
Dissolved organic carbon (DOC) derived from plant litter plays an important role in the ecosystem carbon balance and soil biogeochemistry. However, in boreal coniferous forests no integrated understanding exists of how understory vegetation contributes to litter leaching of DOC, nitrogen $(\mathrm{N})$ and phosphorus $(\mathrm{P})$ with different bioavailability at the forest stand level. We characterized water extractable leachates from fresh and decayed litter of dominant canopy and understory sources in a boreal coniferous forest, in order to explore the contribution of understory vegetation as a source of both total and bioavailable forms of DOC, $\mathrm{N}$ and P. Recently produced litter from deciduous species (including
\end{abstract}

Responsible Editor: Sujay Kaushal.

Electronic supplementary material The online version of this article (https://doi.org/10.1007/s10533-020-00668-5) contains supplementary material, which is available to authorized users.

G. Hensgens $(\square) \cdot$ M. Berggren

Department of Physical Geography and Ecosystem

Science, Lund University, Lund, Sweden

e-mail: Geert.Hensgens@nateko.lu.se;

G.Hensgens@gmail.com

H. Laudon · M. Peichl

Department of Forest Ecology and Management, Swedish

University of Agricultural Sciences, Umeå, Sweden

I. A. Gil · Q. Zhou

Wageningen University, Wageningen, The Netherlands
Vaccinium myrtillus) yielded the highest amounts of DOC. However, this leaching potential decreased exponentially with mass loss through litter decay. The DOC lability generally showed little interspecific variation, although wood derived DOC was more recalcitrant. Lability decreased progressively with litter aging. Water extractable nutrients increased proportionally with DOC, and roughly a quarter $(\mathrm{N})$ or half $(\mathrm{P})$ had directly bioavailable inorganic forms. Scaled to annual litterfall at the forest stand, understory vegetation contributed $\sim 80 \%$ of the water extractable DOC and nutrients from fresh litter, with $>60 \%$ coming from Vaccinium myrtillus alone. However, as litter decomposes, the data suggest a lower leaching potential is maintained with a larger contribution from needle, wood and moss litter. Our study shows that understory vegetation, especially $V$. myrtillus, is a key driver of litter DOC and nutrient leaching in boreal coniferous forests.

Keywords Boreal forest - Dissolved organic carbon $\cdot$ Fennoscandia $\cdot$ Leaching $\cdot$ Litter $\cdot$ V. myrtillus

\section{Introduction}

In boreal terrestrial ecosystems, production rates of dissolved organic carbon (DOC) represent a substantial part of the ecosystem carbon (C) balance (Neff and Asner 2001). The DOC undergoes a variety of soil 
chemical and biological processes, such as microbial mineralization and transformation, or immobilization through adsorption to mineral surfaces (McDowell 2003). Adsorbed DOC contributes to the formation of soil organic matter, which is the largest terrestrial C pool in the global $\mathrm{C}$ cycle (Schlesinger and Bernhardt 2013), while mineralized DOC returns to the atmosphere as $\mathrm{CO}_{2}$. The DOC that is not immobilized or degraded may travel with hydrological paths and contribute to the globally significant transfer of $\mathrm{C}$ from terrestrial to aquatic ecosystems (Cole et al. 2007; Battin et al. 2009; Drake et al. 2018). In addition, DOC is a known vector for the transfer of nutrients, most notably phosphorus $(\mathrm{P})$ and nitrogen $(\mathrm{N})$ (Kalbitz et al. 2000; Kaiser et al. 2001; Harrison et al. 2005). Thus, knowledge on the production and turnover of DOC is important for the understanding of how terrestrial ecosystems function and how they interact with other components in the biosphere.

Soil solution DOC originates from several distinct sources, including plant and microbial litter, soil humus, microbial and root exudates, through-fall and stem-flow (Kalbitz et al. 2000; Stan and Stubbins 2018). In this study we limit the scope to DOC leaching from fresh and aged plant litter, previously suggested to be an important source of DOC in soil solution (Kalbitz et al. 2000). Roughly 10 to $25 \%$ of the litter-fall $\mathrm{C}$ is leached as DOC and transported to forest soil layers (Guggenberger and Kaiser 2003). The bulk of this fresh litter derived DOC does not travel far through the soil column, but tends to be adsorbed to the upper organic or A horizon, while soil DOC at the same layer consists mostly of older DOC (Hagedorn et al. 2002, 2004,2015; Fröberg et al. 2007b, 2007a; Muller et al. 2009; Kammer and Hagedorn 2011; Guelland et al. 2013). Sorption has been shown to stabilize DOC, thereby drastically reducing mineralization rates (Kalbitz et al. 2005) and limiting the contribution of fresh litter DOC to soil $\mathrm{CO}_{2}$ fluxes (Hagedorn et al. 2015). However, there is evidence that a certain exchange takes place in the organic soil layer where DOC from fresh litter sorbs to the organic soil layer while some of the older DOC is released (Muller et al. 2009). A limited amount of DOC may also leach directly to aquatic systems through direct litter input to the rivers (Mcdowell and Fisher 1976; Meyer and Wallace 1998). Thus, fresh litter DOC potentially is an important source of $\mathrm{C}$ not only for shallow soil organic C (SOC) stocks, but in the long term also for $\mathrm{C}$ fluxes to subsoils, aquatic systems and the atmosphere.

The amount and rate of DOC leaching from different litter species show high variability, as does the chemistry and bioavailability of litter leachates (Don and Kalbitz 2005; Wickland et al. 2007; Wymore et al. 2015). This variability is currently poorly understood, complicating accurate modeling of the processes involved in boreal forest $\mathrm{C}$ dynamics (DeLuca and Boisvenue 2012). In order to improve modeling and future projections of soil $\mathrm{C}$ dynamics a better understanding on DOC leaching from litter sources in the boreal forest is needed, especially of the understory sources which currently tend to be overlooked. While the largest proportion of the total biomass in the boreal forests often consists of trees, the understory vegetation is a hotspot for nutrient and C cycling (Nilsson and Wardle 2005; Hart and Chen 2006). Understory net primary production (NPP) estimates range from a fifth to more than half of the ecosystem NPP (Nilsson and Wardle 2005; Kolari et al. 2006; Benscoter and Vitt 2007). These high values should be considered in combination with the fact that the $\mathrm{C}$ cycling in the understory is rapid, exemplified by annual biomass renewal rates of up to $62 \%$ for the common boreal understory species $V$. myrtillus (Nilsson and Wardle 2005). The characteristics of such a dynamic understory imply that large proportions of spring and summer NPP are lost through litter production. The litter $\mathrm{C}$ subsequently is partially respired or leached as DOC to soils in autumn and onwards. In contrast, a relatively larger portion of canopy NPP is allocated to growth and stored as tree biomass.

Litter mass loss, of which litter leaching is an important process (Marschner and Noble 2000; Marschner and Kalbitz 2003), is related to litter chemistry (e.g., $\mathrm{N}$ content) as well as physical properties such as toughness (Perez-Harguindeguy et al. 2000; Preston et al. 2000). Species of the same plant functional type (PFT), or life form, show similar rates of litter mass loss and in general deciduous litter shows higher rates than evergreen species (Cornelissen 1996; Perez-Harguindeguy et al. 2000). Deciduous litter generally also shows higher DOC leaching rates than evergreen species and more tough litter such as wood (Don and Kalbitz 2005; Hagedorn and Machwitz 2007; Wickland et al. 2007; Silveira 2011). It can 
hence be expected that high litter mass loss and high DOC and nutrient leaching rates go hand in hand.

In the coniferous boreal forest deciduous canopy species may be scarce, but large proportions of the understory consist of the common deciduous species V. myrtillus, a species known to show high rates of litter mass loss with a high soluble fraction (Wardle et al. 2003). In addition, the understory moss biomass in boreal systems can be as high as $500 \mathrm{~g} \mathrm{~m}^{-2}$ (Stuiver et al. 2014), and while moss litter both shows low mass loss (Wardle et al. 2003) and DOC leaching (Wickland et al. 2007) the sheer abundance could make it a significant source. Thus, in the coniferous boreal forests, more DOC may be leached from understory than from canopy litter. Considering the diversity in litter quality between and within understory and canopy species, the leachates may as well show a difference in bioavailability. To our knowledge, no previous study has addressed the combined differences in litter production, leaching potentials and bioavailability of the leachates across the understory and canopy components of coniferous boreal forests.

In this study, an extensive inventory was made in the boreal coniferous forest of the Krycklan catchment, northern Sweden, with the objectives to: (i) investigate interspecific differences in water extractable DOC and nutrients (standard laboratory batch extractions with pure water) as related to litter age, and to further assess differences in the bioavailability of the leached DOC and; (ii) determine how DOC leaching is related to litter nutrient chemistry and nutrient leaching. Finally, by combining our leaching measurements with data on in situ litterfall we scaled the water extractable leachates to the forest stand level in order to (iii) investigate the contribution of DOC and nutrient leaching of the understory versus the canopy litter species. As litter structural toughness is related to mass loss (Perez-Harguindeguy et al. 2000) and thus arguably to DOC leaching, we hypothesized that [H1] deciduous leaf litter yields higher total concentrations and more bioavailable water extractable DOC, compared with other more tough sources (coniferous needles, wood litter), but both total concentrations and bioavailability decrease with litter aging. Moreover, because litter mass loss is associated with fresh litter $\mathrm{N}$ content (Perez-Harguindeguy et al. 2000; Preston et al. 2000), we hypothesized that [H2.1] DOC leaching will also be positively correlated to litter $\mathrm{N}$ content. Following this, if high
DOC leaching litter sources have higher litter nutrient content then [H2.2] the leached total and organic concentrations of $\mathrm{N}$ and $\mathrm{P}$ will increase in a positively disproportional way to increased $\mathrm{C}$ leaching. Lastly, with the high annual biomass renewal rates of the boreal understory (Nilsson and Wardle 2005), we expect that $[\mathrm{H} 3]$ the understory vegetation will be responsible for major parts of both total and labile DOC and of nutrient leaching from litter at the forest stand.

\section{Material and methods}

\section{Site description}

The study site is located in the Krycklan catchment near the Svartberget field station in Northern Sweden $\left(64^{\circ} 14.857^{\prime} \mathrm{N}, 19^{\circ} 46.226^{\prime} \mathrm{E}\right)$. The forest research at the Krycklan catchment began around 100 years ago and has focused on hydrology and biogeochemistry since the 1980s (Laudon et al. 2013). The catchment consists of a boreal forest system with numerous headwater streams feeding the Krycklan and subsequently the River Vindelälven, the latter ending in the Gulf of Bothnia. Forest and mire cover about $87 \%$ and 9\% respectively. Dominant tree species are Pinus sylvestris (63\%) and Picea abies (26\%), whereas the understory consists mostly of $V$. myrtillus and $V$. vitisidaea and the peatlands are dominated by Sphagnum spp. A more detailed site description is provided by (Laudon et al. 2013).

Field sampling

Fresh litter material was sampled on September 25 and 28, 2015. The following species were sampled: Picea abies (Norway spruce), Pinus sylvestris (Scots pine), Betula spp. (birch), Alnus spp. and V. myrtillus. To obtain litter that represents the nutritional quality of freshly fallen materials, loosely attached autumn colored leaves and needles were collected directly from the branches, resembling the colors of the litter on the forest floor. Only green leaves were collected for Alnus due to absence of changing coloration. Alnus was included as a nitrogen rich reference litter sample, as the species is known for retracting substantially less nitrogen from its leaves, retaining its green color until senescence (e.g. Dawson and Funk 1981). Litter was 
collected in four replicate samples, each derived from multiple individuals. Branches were collected for all tree species (except Alnus) from fallen or bent trees, or from branches at the base of the trees. For DOC extractions (see further on) only relatively small branches were used $(<5 \mathrm{~mm}$ diameter $)$.

Additional samples of grass (Deschampsia flexuosa), feather moss (Hylocomium splendens, Pleurozium schreberi and Ptilium crista-castrensis), peat and mineral soil material were collected on August 16 and 17, 2016. Grass and moss samples were taken to extend the dataset with understory and ground vegetation litter, but because of the difficulty in determining litter decay in both sources (i.e. new moss grows on previously dead moss and $D$. flexuosa does not shed its leaves, but instead decays mostly standing upright) we did not explicitly address the litter aging effect on DOC leaching for these samples. Soil samples were taken for reference only, but were considered out of the scope of this study. The DOC extracted from soils is a mixture of a variety of DOC sources that besides bulk SOC include microbial components, litter, throughfall, stemflow and root exudates (Hagedorn et al. 2004). Thus, soils are not an original DOC source in the same way as vegetation.

Peat samples were obtained at the Degerö Stormyr mire complex $\left(64^{\circ} 11^{\prime} \mathrm{N}, 19^{\circ} 33^{\prime} \mathrm{E}\right)$ from shallow $(5-15 \mathrm{~cm})$ and deeper depths $(15-25 \mathrm{~cm})$ of the Sphagnum spp. dominated lawn (a mixture of $S$. balticum and $S$. lindbergii). For a more detailed description of the mire see (Nilsson et al. 2008). Peat samples were cut out and taken by hand using gloves without using an augur in order to prevent sample compaction. All other samples were taken from the same location as the litter sampling described above. Grass samples were obtained as whole plants excluding the roots. Moss samples included both dead and alive moss material as both are subjected to DOC leaching. Organic soil samples were taken with a half open cylindrical auger (diameter $\sim 3 \mathrm{~cm}$ ) under Picea abies as well as under Pinus sylvestris vegetation.

After collection, litter samples were oven-dried (40 $\left.{ }^{\circ} \mathrm{C}\right)$ for $24-72 \mathrm{~h}$ and frozen $\left(<-20{ }^{\circ} \mathrm{C}\right)$. Soil and peat samples were oven-dried $\left(40-65{ }^{\circ} \mathrm{C}\right)$ for $6-14$ days and frozen $\left(<-20^{\circ} \mathrm{C}\right)$ before analysis. Fresh litter samples were not cut, as to retain field conditions, but they were homogenized through mixing of samples and combined into composite samples per source. Of each source 15 litter bags (custom-made, 195 micron mesh-size PES) were filled with $10 \mathrm{~g}$ of dry weight litter. The remaining samples were stored at $-24{ }^{\circ} \mathrm{C}$ for further analysis. Litterbags were put in the field underneath the specific source vegetation for maintaining a realistic decomposing environment on October 21, 2016. Litter was rewetted in the field by adding (approximately $30 \mathrm{~mL}$ ) of deionized water to resemble field conditions at the time. At three different time points five litterbags were retrieved for each species/structure: after 10 days, after first snow fall (December 8, 2016) and just before complete snow melt (April 18, 2017). Recollected samples were stored at $\left(<-20{ }^{\circ} \mathrm{C}\right)$ before transport and then at $-24{ }^{\circ} \mathrm{C}$ before further analysis.

\section{Dissolved organic carbon extraction}

Water extractable DOC (potential leaching) was determined in pure water laboratory batch extractions. While pure water DOC extractions are not directly translatable to in situ field fluxes, they represent a better controlled environment in which environmental factors are excluded and litter DOC leaching between different litter sources can be compared in a straightforward way. There exists a rich literature concerning laboratory batch DOC extractions that have pinpointed interspecific differences and processes of DOC leaching both in litter and soils (Kalbitz et al. 2003; Don and Kalbitz 2005; Wickland et al. 2007; Silveira 2011; Schreeg et al. 2013b; Wymore et al. 2015), as well as literature explaining the limitations and possibilities of the methods (Kalbitz et al. 2000; Zsolnay 2003; McDowell et al. 2006).

Extractions were performed with 1 or $2 \mathrm{~g}$ of homogenized dry sample added to $40 \mathrm{~mL}$ of milli-Q water in $60 \mathrm{~mL}$ polypropolene Falcon tubes. Tubes were then put on a shaker machine (RPM 140) for $48 \mathrm{~h}$. The DOC was separated by filtration $(0.7 \mu \mathrm{m}$ Whatman GF/F). Part of the filtrate was diluted before measuring DOC on a Shimadzu TOC V-CPN analyzer, using the Nonpurgeable Organic Carbon mode (Herzog and Kritzberg 2017). After measurements all samples were diluted to $6 \mathrm{mg} \mathrm{C} \mathrm{L}^{-1}$ after nutrient and inoculum addition. The inoculum consisted of a mixture of water from 6 lakes and 6 streams of the study area to ensure the presence of sufficient microbial diversity in the incubation and was added as $1 \%$ $(\mathrm{v} / \mathrm{v})$ of the total volume. A nutrient solution was 
added (as $\mathrm{NH}_{4} \mathrm{NO}_{3}$ and $\mathrm{K}_{2} \mathrm{PO}_{4}$ ) to achieve an end solution with an approximate $\mathrm{C}: \mathrm{N}: \mathrm{P}$ ratio of 25:5:1. Before the addition of nutrients and inoculum, part of the diluted DOC solutions were sub-sampled and stored at $-24{ }^{\circ} \mathrm{C}$ for nutrient analysis.

Incubation experiments

Dark incubation experiments were initiated in high density polyethylene bottles within two days from DOC extraction. Short term incubation was done in duplicates for each DOC solution using SDR (SensorDish Readers, PreSense) nonintrusive oxygen sensors for respiration monitoring in $5 \mathrm{~mL}$ glass vials (Soares et al. 2018). Short term incubations were run for 7 days with measurements every $2 \mathrm{~h}$ in a closed climate chamber at $20^{\circ} \mathrm{C}$. Parallel to this a long-term incubation experiment was started on 300 to $400 \mathrm{~mL}$ of the same solution in 0.5 L HDPE bottles in a dark constant room at $20^{\circ} \mathrm{C}$. The DOC concentrations (mg $\mathrm{C} \mathrm{L}^{-1}$ ) from all fresh litter samples was measured at start and after 2, 4, 6, 12, 28 and 52 weeks of incubation. To reduce the number of analyses, incubations of aged litter, moss, peat, grass and soil leachates were measured for DOC only 3 times during the long-term incubation experiment: at start and after 4 and 28 weeks. At each time point $30-40 \mathrm{~mL}$ sample water was acidified using $50 \mu \mathrm{l}$ of ultrapure (20\%) $\mathrm{HCl}$ before storage at $5{ }^{\circ} \mathrm{C}$. The DOC analysis was performed on an OI analytical Aurora TOC analyzer.

\section{DOC decay dynamics}

Changes in dissolved oxygen concentrations $\left(\mathrm{O}_{2}\right)$ during incubation were used together with the known initial DOC values (at $t=0$ ) to infer DOC concentrations at any given time point $(\mathrm{t})$ according to Eq. 1, where $C_{\text {mass }}$ is the molar mass of $\mathrm{C}$ and $O 2_{\text {mass }}$ is the molar mass of dioxygen.

$D O C_{t}=\left(\frac{D O C_{t=0}}{C_{\text {mass }}}-\frac{O 2_{t=0}-O 2_{t}}{O 2_{\text {mass }}}\right) C_{\text {mass }}$

Converting $\mathrm{O}_{2}$ concentrations to DOC concentrations in this way assumes that for every depleted molecule of $\mathrm{O}_{2}$ one atom of $\mathrm{C}$ is being used, i.e. it assumes a respiratory quotient (RQ) of 1 . This is close to RQs measured in soils (Muller et al. 2004; Dilly and Zyakun 2008) and well within the range of RQ as found for decay processes of DOC in aquatic systems (Berggren et al. 2012).

Short- and long-term incubation data was merged and DOC concentrations were converted into DOC mineralization (\% of initial DOC). Because of an overrepresentation of data points from the first seven days when measurements were done with 2-h interval, only 7 points at a fixed daily interval were used for the subsequent double exponential decay curve fitting. For the moss species only 3 points (day 1 to 3 ) could be used due to exhaustion of the available oxygen in these short-term incubations. The same problem existed for a number of different samples where instead only 5 days of the short-term incubation were used.

A double exponential model (Eq. 2) was fitted on the combined short and long-term incubation data as suggested in (Kalbitz et al. 2003), where $\alpha$ is the amount of labile DOC (\%), $t$ is time (days) $k 1$ and $k 2$ are the decay constants for the labile and recalcitrant DOC respectively. Fitting was done on individual replicates, after which the parameters were averaged for each distinct sample.

$$
\begin{aligned}
\text { Mineralized DOC }= & a\left(1-e^{-k 1 * t}\right)+(100 \\
& -a)\left(1-e^{-k 2 * t}\right)
\end{aligned}
$$

The model was fitted using the nonlinear least squares (nls) function in R3.4.1 (R Core Team 2016). Starting values were estimated according to Don and Kalbitz and set at $\alpha=70, k 1=0.3$ and $k 2=0.001$ (Don and Kalbitz 2005). The Port algorithm was used with lower boundaries set to 0 for the $k 1$ and $k 2$ parameters. Four samples showed a convergence error during fitting that could not be resolved-meaning that the data points of these incubations did not follow the typical double exponential decay curve and were excluded from subsequent data analysis (one pine wood, one spruce litter and two Alnus samples).

Total N, total organic N, total P, total organic $\mathrm{P}$

Diluted replicate samples were combined and stored at $-24{ }^{\circ} \mathrm{C}$ before analysis of total nitrogen $(\mathrm{TN})$, total phosphorus (TP), phosphate $\left(\mathrm{PO}_{4}\right)$, ammonia $\left(\mathrm{NH}_{4}\right)$ and nitrite and nitrate $\left(\mathrm{NO}_{\mathrm{x}}\right)$ at the Erken Laboratory (Uppsala University, Sweden) using a Seal AutoAnalyzer 3 (Norderstedt Germany) according to the standardized methods for TN, $\mathrm{NH}_{4} \mathrm{NO}_{\mathrm{x}}(G-384-08$ Rev. 2 \& G-172-96 Rev. 12, G-171-96 Rev. 15 and 
G-384-08 Rev.2 respectively) and for TP and $\mathrm{PO}_{4}(G-$ 175-96 Rev. 1 and G-297-03 Rev. 15 respectively). Total organic nitrogen (TON) was calculated as the difference between $\mathrm{TN}$ and $\mathrm{NH}_{4} \& \mathrm{NO}_{\mathrm{x}}$ and total organic phosphorus (TOP) as the difference between $\mathrm{TP}$ and $\mathrm{PO}_{4}$. Analyses were done for each timepoint that DOC was extracted.

Litterfall, understory vegetation biomass and scaling DOC

A total of 50 forest plots (10 m radius) were selected encompassing a representative range in the dominant tree species (pine, spruce or birch), aboveground tree biomass (as a proxy for stand age), management practices (clear cut, thinned, fertilized, old growth), and soil types (till and sediment) across the Krycklan catchment. In each plot, 3 litterfall traps $\left(0.25 \mathrm{~m}^{2}\right)$ were placed $1 \mathrm{~m}$ above the forest floor during August 2016. Collection of litterfall occurred from October 2016 to November 2018 at bi-weekly intervals during the peak litterfall period in autumn (i.e. mid-September to mid-October) and at the end of each winter, spring and summer season. The collected litter was first air dried and then oven dried (for $24 \mathrm{~h}$ at $80^{\circ} \mathrm{C}$ ), and subsequently sorted into following categories: (1) deciduous; (2) coniferous needles; (3) cones; and (4) branches + bark. The weight was then determined separately for each category. Annual litterfall rates for 2016, 2017 and 2018 were determined for each plot by summing the amount of litterfall from November (of the previous year) to October. To obtain an annual estimate in 2016, the missing but relatively small contribution of litterfall during winter, spring and summer was estimated as the average from the respective seasons in 2017 and 2018.

Understory aboveground biomass was quantified via destructive sampling (i.e. clipping) from three micro-plots $(25 \times 25 \mathrm{~cm})$ per forest plot in August 2017. The collected samples were first sorted into plant functional type (PFT: moss, lichen, graminoid, woody shrubs as well as fine woody debris), then oven-dried at $65{ }^{\circ} \mathrm{C}$ for $24 \mathrm{~h}$ and weighted. Photographs were taken from each plot to visually assess the contribution of the various species within each PFT to the total area cover. To obtain an estimate of the litter production by Vaccinium myrtillyus we used the measured dry biomass of shrubs, together with information gathered about the dominant species per plot and photographs to get an approximate estimate of the percentage of shrub biomass belonging to Vaccinium myrtillyus. We then used the yearly biomass renewal rate of $62 \%$ (Nilsson and Wardle 2005) to calculate the litter production and assumed all renewal rate to result into leaf litter.

Scaling of DOC to forest stand level was done by first calculating the litterfall per species using the litterfall measurements and average tree cover of the catchment (Laudon et al. 2013). For moss and grass the standing biomass of moss and graminoids was used. Potential DOC leaching for fresh litter was then calculated by multiplying fresh litter water extractable DOC with annual litterfall (Table 1). However, because leaching in batch experiments does not equal in situ leaching rates in terms of total quantity, the data in Table 1 should not to be used as estimates of in situ litter DOC leaching. The aim of the article was not to present precise in situ DOC leaching numbers, but instead to investigate interspecific differences in total and labile DOC and nutrient leaching at the forest stand level and investigate the role of the understory as related to canopy sources.

\section{Statistics}

Statistics were done using the $\mathrm{R}$ program ( $\mathrm{R}$ Core Team 2016) standard functions, the nre package for fitting of mixed effect models and the emmeans and multcomp packages for subsequent post-hoc testing.

\section{DOC leaching as related to litter mass loss}

A linear mixed effect (LME) model was used to test the difference between the relationship of DOC leaching and mass loss of different litter species. Species was used as fixed effects, with the wood species grouped together, and replicates were set to random effect. The reference species was set to $V$. myrtillus, and post-hoc testing was done using Tukey's HSD test.

\section{The relationship between nutrients and DOC leaching}

To test the hypothesis that nutrient to $\mathrm{C}$ leaching increases with increased DOC leaching a LME model was used. The model used nitrogen type (i.e. TN or DON) or phosphorus type (i.e. TP or TOP) as fixed effects for the relationship between nitrogen or 
Table 1 Calculation for the scaled DOC leaching per species $\left(\mathrm{mg} \mathrm{g}^{-1}\right)$

\begin{tabular}{llllr}
\hline & DOC $\left(\mathrm{mg} \mathrm{g}^{-1}\right)$ & Tree cover $(\%)$ & Litterfall $\left(\mathrm{g} \mathrm{m}^{-2}\right)$ & DOC $\left(\mathrm{mg} \mathrm{m}^{-2}\right)$ \\
\hline Grass & $13.4(3.8)$ & na & 25.2 & $337(95.5)$ \\
Moss & $11.8(2.2)$ & na & 230 & $2726(502)$ \\
Alnus & $57.2(4.1)$ & 1 & 2.5 & $142(10.3)$ \\
Birch 1 & $49.7(2.4)$ & 10 & 24.8 & $1262(58.4)$ \\
Birch w & $1.0(0.2)$ & 11 & 1.6 & $1.5(0.35)$ \\
Pine 1 & $5.9(0.4)$ & 63 & 66.8 & $395(27.8)$ \\
Pine w & $3.8(0.6)$ & 63 & 9.8 & $37.1(5.6)$ \\
Spruce 1 & $12.1(0.9)$ & 26 & 27.6 & $332(23.9)$ \\
Spruce w & $2.0(0.8)$ & na & 4.0 & $8.0(3.3)$ \\
Vaccinium & $138(5.0)$ & 77.5 & $10,713(386)$ \\
\hline
\end{tabular}

Litterfall was measured for needle, deciduous and wood canopy sources, biomass for moss, grasses and shrubs. Tree cover (\%) was used to determine litterfall $\left(\mathrm{g} \mathrm{m}^{-2}\right)$ on species level. For moss and grass biomass was taken as litter estimate, for Vaccinium biomass was multiplied with the yearly renewal rate. Scaled DOC leaching $\left(\mathrm{mg} \mathrm{m}^{-2}\right)$ was calculated as the amount of DOC leaching $\left(\mathrm{mg} \mathrm{g}^{-1}\right)$ multiplied with litterfall. Standard deviation in brackets; $n=4$. Tree cover percentages from (Laudon et al. 2013)

phosphorus leaching and DOC leaching. Random effects were set to species. Since DOC, TN, DON, TP and TOP all had a right skewed distribution all variables were Log10 transformed. A linear model on Log-Log transformed data is the same as a power function with the slope $(\alpha)$ of the model equal to the exponent and the intercept $(\beta)$ equal to the slope of the power function (Eq. 3).

$y=\beta x^{\alpha}$

The model thus shows the slope $(\beta)$ as a rate of increased nutrient leaching with increased DOC leaching, and the exponent $(\alpha)$ as a possible deviation from a linear regression. Significance deviance of the exponent was rejected if 1 fell within the $95 \%$ interval.

\section{DOC lability}

To test how litter decay affects the lability of leached DOC a non-linear mixed model (NLME) was fitted using Eq. 2, with litter decay time as a fixed effect and species as a random factor. To test whether there was a significant difference in lability between the species 4 different NLME models were made for each different time, using species as a fixed effect and replicate as a random factor. Because of fitting problems birch wood was removed for the model of the 10-day decayed litter DOC. Post-hoc testing was done using Tukey's HSD.
Where shown, the Akaike Information Criterion (AIC) was calculated as an estimator of the relative quality of the model. The $\mathrm{R}^{2}$ of the fixed effects was approximated using the MuMIn package in $\mathrm{R}$, which allows for calculation of $\mathrm{R}^{2}$ values of general linear mixed models with the function r.squaredGLMM.

\section{Results}

Leaching of DOC, litterfall and scaled tree stand proportions

Leaching of DOC from fresh litter was in the range of $2 \mathrm{mg} \mathrm{C} \mathrm{g}^{-1}$ for spruce wood to $138 \mathrm{mg} \mathrm{C} \mathrm{g}^{-1}$ for $V$. myrtillus litter (Fig. 1a, b). Organic soil material, in comparison, leached DOC at $5 \mathrm{mg} \mathrm{C} \mathrm{g}^{-1}$ or lower (Fig. 1c). As litter decomposed, DOC leaching decreased exponentially (Fig. 1a) except in the case of $P$. sylvestris and combined wood litter, where instead leaching increased with mass loss (Fig. 1b). As a result, the variation of DOC leaching per gram of litter of all sources dropped and converged at 5-15 mg $\mathrm{C} \mathrm{g}^{-1}$ after 180 days of field litter decomposition. The highest DOC leaching per gram of dry weight was found for Vaccinium litter for all decay stages, followed by the other deciduous, needle and then wood litter. Source material from grass and moss (Fig. 1c) had leachable DOC values comparable to 

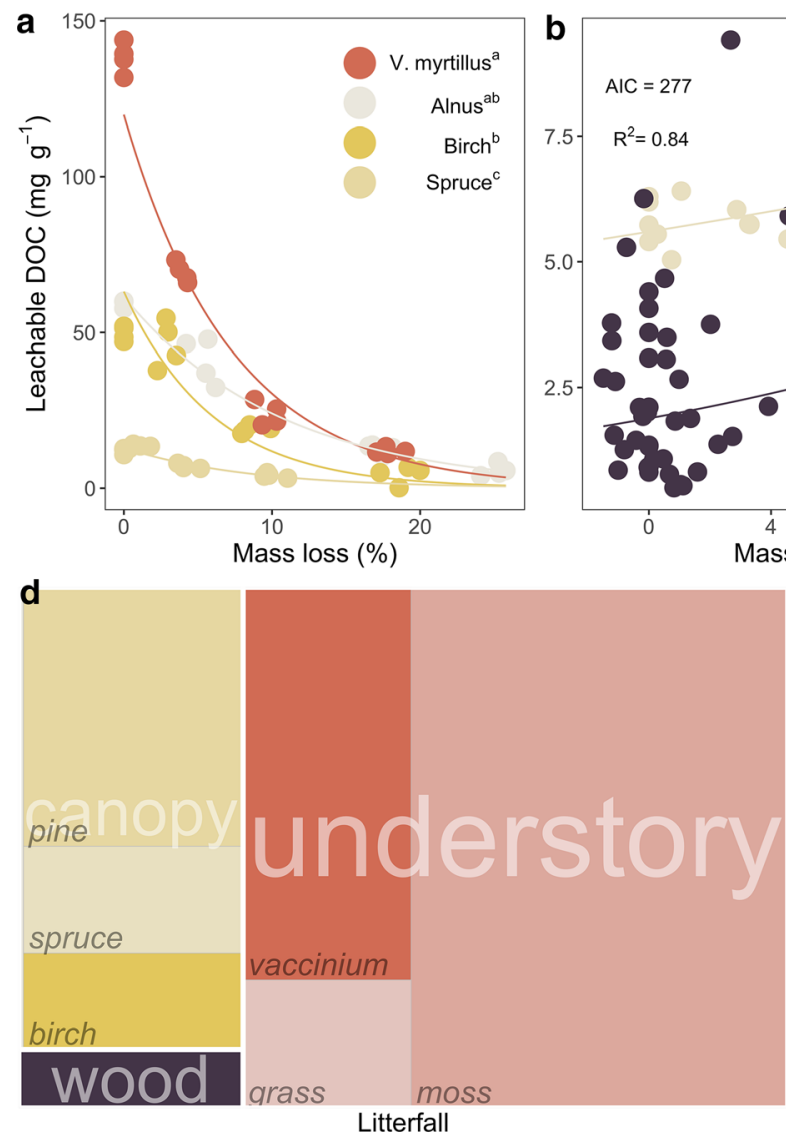

Fig. 1 a, b DOC leaching ( $\mathrm{mg} \mathrm{g}^{-1}$ dry weight litter) as related to litter mass loss of a Vaccinium, alnus, birch and spruce litter, and $\mathbf{b}$ pine and wood litter. The marginal $\mathrm{R}^{2}$ and AIC is shown for a linear mixed effects model, applied on the data across panels a, b, with species as fixed effects and replicates as random effect. Different superscripted index letters denote significant interspecific differences $(p<0.05)$ in both intercept and slope (Tukey's HSD post hoc test). $\mathbf{c}$ DOC leaching ( $\mathrm{mg} \mathrm{g}^{-1}$

fresh spruce litter $\left(13.4,11.8\right.$ and $12.1 \mathrm{mg} \mathrm{g}^{-1}$ respectively).

Leaching of DOC was not related to the chemical composition or stoichiometry of the source material (Supplementary Table 1). However, 10-, 48- and 180-day mass loss of litter was correlated to fresh litter $\mathrm{N}$ content $\left(\mathrm{r}^{2}=0.75,0.62\right.$ and 0.62 , respectively) where mass loss exponentially increased with the litter source initial N content. This relationship was strongly driven by Alnus litter which, if excluded, turned the relationships linear with poorer correlation $\left(\mathrm{r}^{2}=0.43\right.$, 0.14 and 0.29 , respectively). In addition, the leaching of DOC from fresh or progressively aged litter exponentially increased as related to total (180 day)
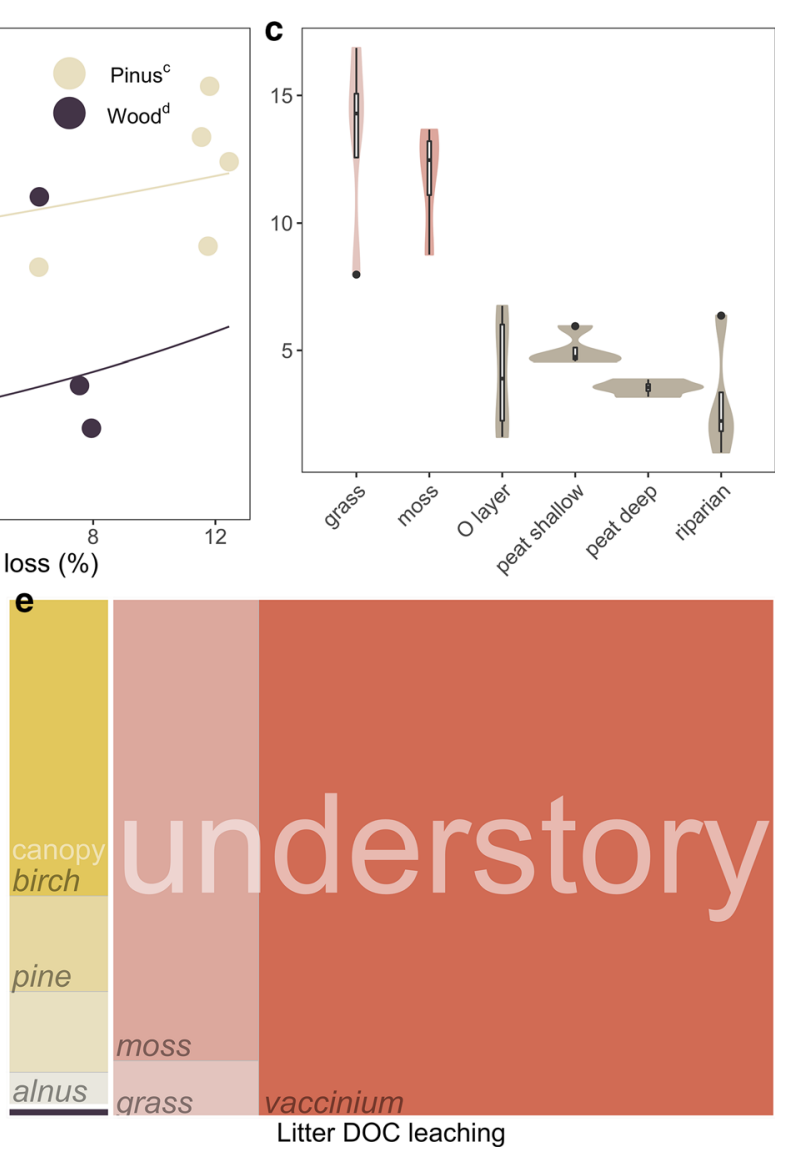

dry weight) of grass, moss and soil reference samples. d-e Relative contributions from the different species to $\mathbf{d}$ litterfall and $\mathbf{e}$ DOC leaching at the forest stand level. In e, the scaled distribution of DOC leaching is derived from the multiplication of fresh litter DOC leaching rates from panels a-c (except reference soil samples) with litterfall the distribution from panel d

litter mass loss $\left(r^{2}=0.84,0.81,0.79\right.$ and 0.64 respectively).

Although annual litterfall of the canopy was roughly a factor two higher than understory litterfall (not counting moss standing biomass), understory fresh litter DOC leaching (69\%) was 5.3 times higher than leaching from canopy sources (13\%) (Fig. 1d-e). Including standing moss biomass, which accounted for almost half of the annual litter-mass, added another $17 \%$ to the understory litter leachable DOC potential making it more than 6.5 times higher than the canopy potential. Vaccinium litter contributed $67 \%$ and grasses $2 \%$ of the total water extractable DOC. Within the canopy sources, birch (8\%) contributed most to the 
total DOC leaching, followed by pine (2\%), spruce $(2 \%)$, Alnus $(1 \%)$ and all combined wood sources $(<1 \%)$.

The relationship between nutrient and DOC leaching

Nutrients leached in proportion to the DOC leaching, with the lowest leaching occurring for litter sources with low DOC leaching potentials (Fig. 2). The leaching of $\mathrm{N}$ ranged from 14 to $12,629 \mu \mathrm{g} \mathrm{g}^{-1}$ litter with on average more than half leached as DON $(53.3 \pm 27.2 \%)$. The leaching of $\mathrm{P}$ ranged from 10 to $1924 \mu \mathrm{g} \mathrm{g}^{-1}$ litter with roughly a quarter leached as DOP $(23.1 \pm 18.9 \%)$. The exponents of the LME power regression model (Eq. 3) fitted to our data were not significantly different to 1 ( $95 \%$ interval of TN 0.89-1.73, TP $0.43-1.08$ ), so the proportion of $\mathrm{N}$ or $\mathrm{P}$ released per $\mathrm{mg}$ of DOC did not statistically change as more DOC was leached.

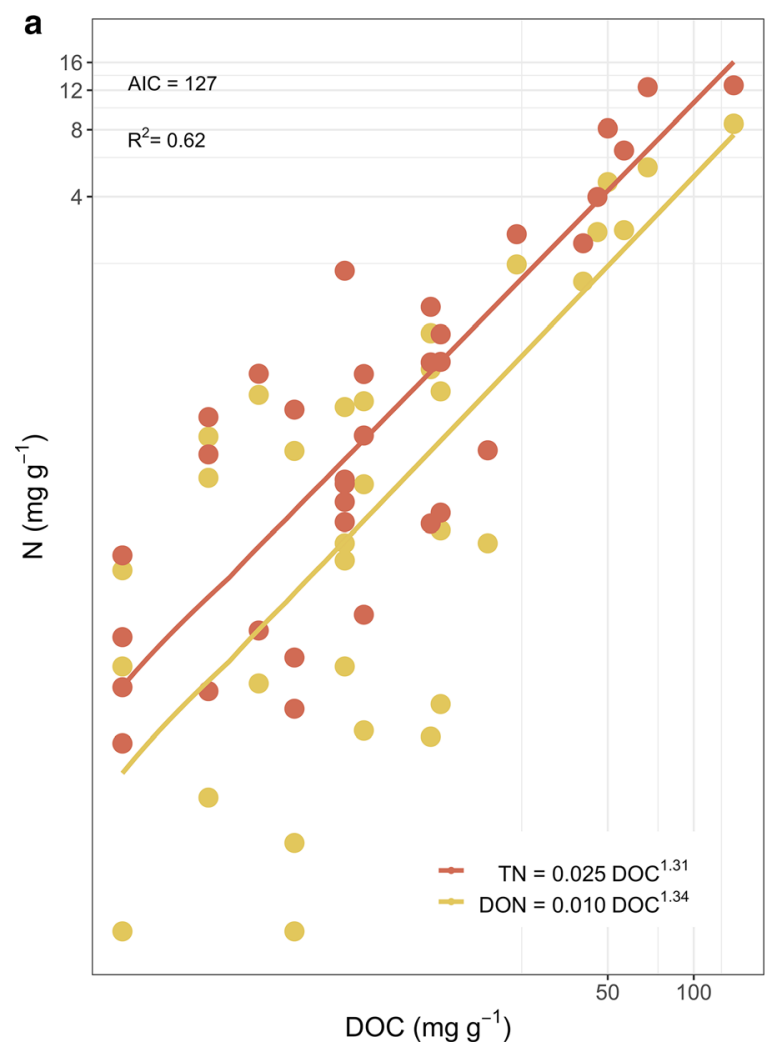

Fig. 2 Log-Log graph of a TN and DON, and b TP and DOP leaching ( $\mu \mathrm{g} \mathrm{g}^{-1}$ dry weight litter) as related to DOC leaching ( $\mathrm{mg} \mathrm{g}^{-1}$ dry weight litter). The AIC and the marginal $\mathrm{R}^{2}$ as well
Leaching of nutrients was not related to the chemical stoichiometry of the source material (Supplementary Tables 1, 2).

\section{Decay of DOC}

A substantial variation in decay of DOC was seen in the decay model across plant species and litter types (Table 2). At the start of the incubation decay rates were at their highest, and approximately $15-65 \%$ of the DOC was mineralized within 7 days (Fig. 3). Over time decay rates decreased, following the fitted exponential decay model (Eq. 2) as seen in Table 2 and Fig. 3. Initially litter decomposition slightly increased lability of DOC (after 10 days), but turned into a decreased lability (after 48 and 180 days; Table 3). Groups of litter species with statistically equally labile DOC fractions $(a)$ were largely overlapping, with needle, deciduous and wood litter often found within the same groups (Table 2). The Alnus and

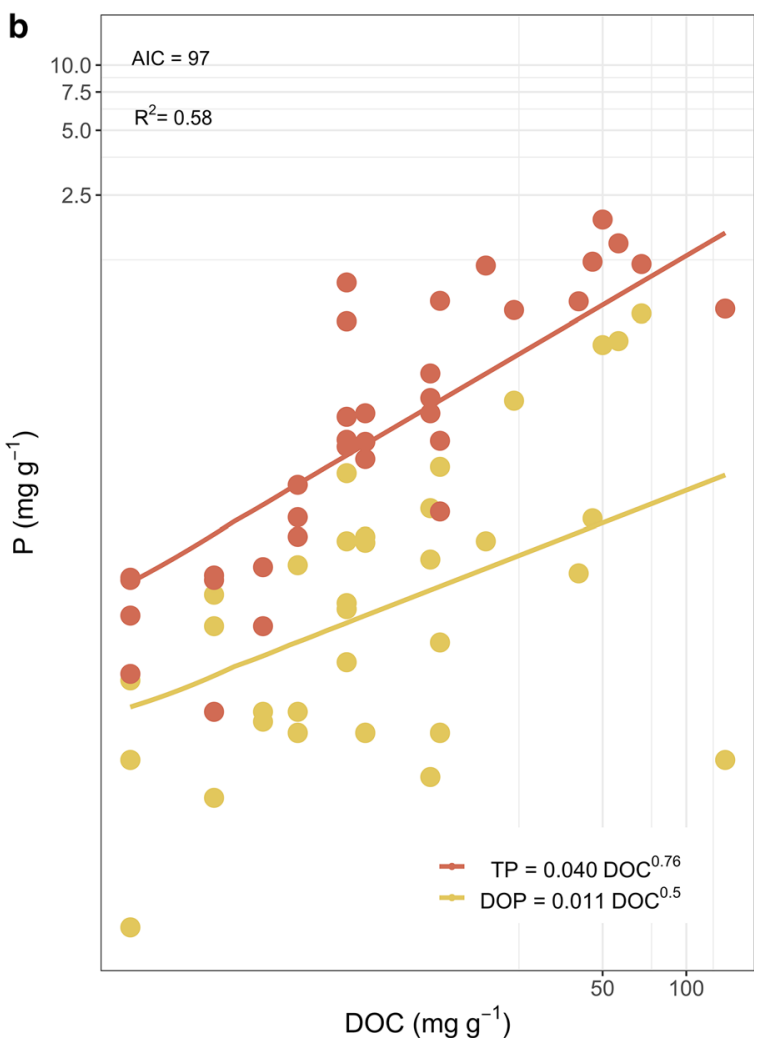

as the formula are given for a linear mixed effects model with nutrient type (i.e. organic or total) as fixed effects and species as random effect 
Table 2 Modelled DOC mineralization

\begin{tabular}{|c|c|c|c|c|}
\hline Species & Labile fraction $(\%)$ & $\mathrm{k}_{1} \mathrm{t}_{1 / 2}$ & $\mathrm{k}_{2} \mathrm{t}_{1 / 2}$ & Average RSE \\
\hline \multicolumn{5}{|c|}{ DOC extracted from fresh litter } \\
\hline Grass & $72.9(1.9)$ & $2.6(0.4)$ & $176.5(15.4)$ & $4.1(0.8)$ \\
\hline Moss & $74(1.1)$ & $2.3(0.5)$ & $286.4(26.5)$ & $3.6(0.7)$ \\
\hline Alnus & $81.9(1.3)^{\mathrm{a}}$ & $3.9(0.2)^{\mathrm{a}}$ & $519.5(218.3)$ & $6.7(0.2)$ \\
\hline Birch 1 & $78.7(1.8)^{\mathrm{a}, \mathrm{b}, \mathrm{c}}$ & $4.2(0.1)^{\mathrm{a}, \mathrm{b}}$ & $421.6(150.4)$ & $4.6(0.3)$ \\
\hline Birch w & $54.7(11.2)^{\mathrm{a}, \mathrm{b}, \mathrm{c}, \mathrm{d}}$ & $8.3(1.6)^{\mathrm{e}}$ & 670 (NA) & $3.3(0.9)$ \\
\hline Pine 1 & $70.3(2.2)^{\mathrm{c}}$ & $6.4(0.5)^{\mathrm{c}, \mathrm{d}}$ & $1295.7(1246.8)$ & $3.1(0.3)$ \\
\hline Pine w & $78.1(3.5)^{\mathrm{a}, \mathrm{b}, \mathrm{c}}$ & $4.9(0.6)^{\mathrm{b}}$ & $364.4(64.1)$ & $3.2(0.7)$ \\
\hline Spruce 1 & $79.9(3.3)^{\mathrm{a}, \mathrm{b}}$ & $5.2(0.6)^{\mathrm{b}, \mathrm{c}}$ & $678.6(468.4)$ & $2.7(0.3)$ \\
\hline Spruce $\mathrm{w}$ & $54(3.4)^{\mathrm{d}}$ & $8.9(1.9)^{\mathrm{d}, \mathrm{e}}$ & $573.8(96.7)$ & $2.5(0.5)$ \\
\hline Vaccinium & $73.5(2.3)^{\mathrm{b}, \mathrm{c}}$ & $4.7(0.3)^{\mathrm{a}, \mathrm{b}}$ & $295.7(75.4)$ & $2.5(0.5)$ \\
\hline \multicolumn{5}{|c|}{ DOC extracted from 10 days decomposed litter } \\
\hline Alnus & $77.4(3.4)^{\mathrm{a}, \mathrm{b}}$ & $3.9(0.5)^{\mathrm{a}}$ & $209.3(24.3)$ & $5.1(0.4)$ \\
\hline Birch 1 & $76.2(2.1)^{\mathrm{a}, \mathrm{b}, \mathrm{c}}$ & $5.8(0.7)^{\mathrm{b}, \mathrm{c}}$ & $415.8(152.5)$ & $4.7(0.9)$ \\
\hline Birch w & $55.8(2.8)$ & $13.6(1.4)$ & NA & $6.2(2.1)$ \\
\hline Pine 1 & $69(7.4)^{\mathrm{a}, \mathrm{b}}$ & $8.5(2.3)^{\mathrm{d}}$ & 469 (55.6) & $3.2(0.3)$ \\
\hline Pine $\mathrm{w}$ & $79.7(4.4)^{\mathrm{c}}$ & $6.1(2.2)^{\mathrm{c}, \mathrm{d}}$ & $278.1(80)$ & $4.4(1)$ \\
\hline Spruce 1 & $81.5(4.2)^{\mathrm{a}, \mathrm{b}, \mathrm{c}}$ & $6.5(1)^{\mathrm{b}, \mathrm{c}, \mathrm{d}}$ & $842.1(662.4)$ & $0.9(0.5)$ \\
\hline Spruce w & $59(3.2)^{\mathrm{a}}$ & $17(0.5)^{\mathrm{e}}$ & NA & $2.3(1)$ \\
\hline Vaccinium & $86.3(1.6)^{\mathrm{b}, \mathrm{c}}$ & $5.2(0.9)^{\mathrm{b}}$ & $1148.9(992.9)$ & $2(0.6)$ \\
\hline \multicolumn{5}{|c|}{ DOC extracted from 48 days decomposed litter } \\
\hline Alnus & $81.3(1.3)^{\mathrm{a}}$ & $8.3(1.2)^{\mathrm{c}}$ & NA & $4.7(0.3)$ \\
\hline Birch 1 & $63.8(1.4)^{\mathrm{b}}$ & $5.2(0.8)^{\mathrm{b}}$ & $316.3(42.4)$ & $4.5(0.1)$ \\
\hline Birch w & $39.2(8.2)^{\mathrm{c}}$ & $4.8(1.2)^{\mathrm{b}}$ & $410.5(86.6)$ & $2.8(0.1)$ \\
\hline Pine 1 & $65.5(1.4)^{\mathrm{b}}$ & $6.3(0.4)^{\mathrm{b}}$ & $336.8(63.6)$ & $3.9(0.3)$ \\
\hline Pine $w$ & $70.8(3.1)^{\mathrm{b}}$ & $5.4(0.4)^{\mathrm{b}}$ & $244.5(39.9)$ & $4.7(0.3)$ \\
\hline Spruce 1 & $71.1(4.5)^{\mathrm{b}}$ & $7(1.4)^{\mathrm{b}, \mathrm{c}}$ & $277.4(64.1)$ & $3.4(0.5)$ \\
\hline Spruce w & $38.5(4.2)^{\mathrm{c}}$ & $6(1.3)^{b}$ & $232.5(25.2)$ & $3.1(0.2)$ \\
\hline Vaccinium & $48(4.1)^{\mathrm{c}}$ & $2.8(0.6)^{\mathrm{a}}$ & $226.6(22.5)$ & $3.5(0.4)$ \\
\hline \multicolumn{5}{|c|}{ DOC extracted from 180 days decomposed litter } \\
\hline Alnus & $59.5(18.4)^{\mathrm{a}, \mathrm{b}}$ & $5.4(3)^{\mathrm{a}, \mathrm{b}, \mathrm{c}}$ & $166.2(10.7)$ & $4.5(1.1)$ \\
\hline Birch 1 & $56.1(5.4)^{\mathrm{b}}$ & $4(1.6)^{\mathrm{a}}$ & $432.3(214.6)$ & $4.1(1)$ \\
\hline Birch w & $31.7(4.3)^{\mathrm{c}}$ & $3.9(1.2)^{\mathrm{a}, \mathrm{b}}$ & $580.9(226)$ & $2.9(0.4)$ \\
\hline Pine 1 & $64.4(6.7)^{\mathrm{a}, \mathrm{b}}$ & $8(1.5)^{\mathrm{c}, \mathrm{d}}$ & $2090.9(2527.5)$ & $3.3(0.1)$ \\
\hline Pine w & $74.3(1.6)^{\mathrm{a}}$ & $10.3(2.3)^{\mathrm{d}}$ & $995.1(405.3)$ & $3.9(0.3)$ \\
\hline Spruce 1 & $64(3.9)^{\mathrm{a}, \mathrm{b}}$ & $10(0.9)^{\mathrm{d}}$ & $657.5(213.6)$ & $3.7(0.2)$ \\
\hline Spruce w & $46.1(8.8)^{\mathrm{b}, \mathrm{c}}$ & $7.7(2)^{\mathrm{b}, \mathrm{c}, \mathrm{d}}$ & $527.9(376)$ & $3.9(0.1)$ \\
\hline Vaccinium & $48.5(6.3)^{\mathrm{b}}$ & $7.1(1.4)^{\mathrm{b}, \mathrm{c}, \mathrm{d}}$ & $540.6(348.8)$ & $3.7(0.2)$ \\
\hline \multicolumn{5}{|c|}{ DOC extracted from soils } \\
\hline Pine humus & $63.3(17.2)$ & $13.3(3.1)$ & 247.6 (NA) & $2.5(1.1)$ \\
\hline Spruce humus & $60.6(13.6)$ & $13.9(4)$ & 361.9 (NA) & $1.9(0.5)$ \\
\hline Peat deep & $79.4(3.2)$ & $12.9(0.8)$ & NA & $2.5(0.5)$ \\
\hline Peat shallow & $67.6(2.4)$ & $6.8(0.6)$ & $269.4(88.3)$ & $3.7(0.3)$ \\
\hline Riparian & $68.1(6.8)$ & $7.9(2.4)$ & $924.7(1164.5)$ & $2.3(1.9)$ \\
\hline
\end{tabular}


Table 2 continued

\begin{tabular}{lllll}
\hline Species & Labile fraction $(\%)$ & $\mathrm{k}_{1} \mathrm{t}_{1 / 2}$ & $\mathrm{k}_{2} \mathrm{t}_{1 / 2}$ & Average RSE \\
\hline $\begin{array}{l}\text { DOC from a glucose control } \\
\text { Glucose }\end{array}$ & 91.4 (NA) & $4.3(\mathrm{NA})$ & $\mathrm{NA}$ & 12 (NA) \\
\hline
\end{tabular}

Litter is fresh or has been field decomposed for 10, 48 and 180 days. The labile fraction is the a parameter in the model. The half-life of the labile and stable pool are given as $\mathrm{k}_{1}$ and $\mathrm{k}_{2}$. Average RSE is the mean residual standard error of the models fitted on the incubations. Standard deviation is given in brackets; $n=4$. NA (not available) is missing standard deviations due to a sample size of $\mathrm{n}=1$-e.g. for glucose, or for when only one $k 2$ of the 4 models was fitted (i.e. the others were fit to 0 )

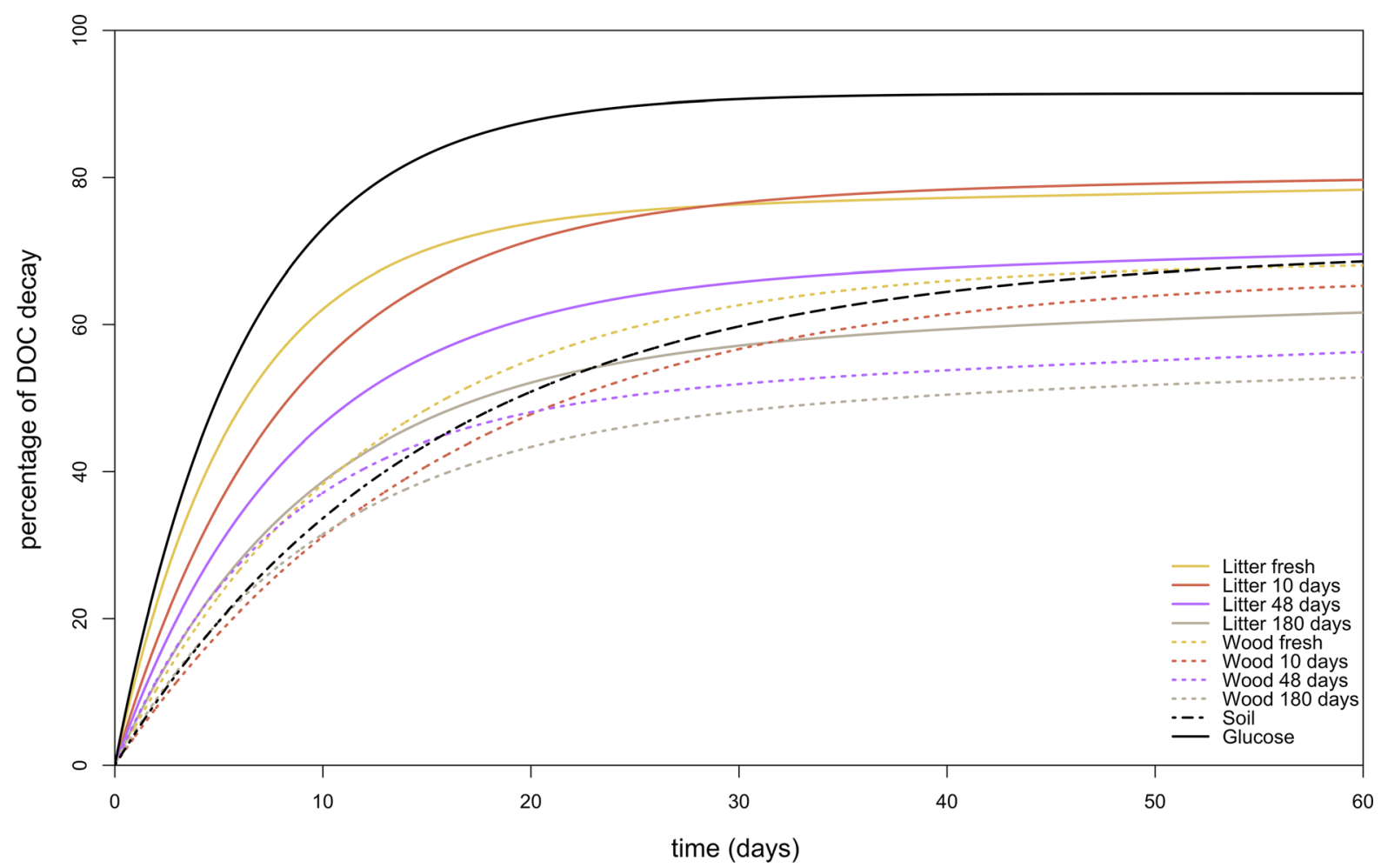

Fig. 3 The first 60 days of the DOC incubation, showing the fitted double exponential decay model for the averaged of leaf litter, wood and soil derived DOC. Solid lines are leaf litter,

birch litter were often part of the most labile group, at times accompanied with pine or spruce litter. $V$. myrtillus was usually found within the second to- or highest labile group. Spruce and birch wood were overall part of the group that showed lowest lability. In general litter was more labile than wood (Fig. 3), although pine wood was surprisingly labile relative to other wood and litter species (Table 2). The DOC derived from soils had a comparable lability to interrupted wood. Yellow is fresh, orange 10 days, purple 48 days and grey 180 days field decayed litter. Dotted black lines are soils. The solid black line is the glucose reference

180 days field decomposed litter or fresh wood litter (Fig. 3).

\section{Discussion}

In support of our first hypothesis, fresh deciduous leaf litter yielded the highest water extractable DOC per gram of dry litter, by more than four times that of needle or wood litter. Leaching rates of the shrub 
Table 3 Results from the NLME showing the labile fraction (a), labile decay rate $(\mathrm{k} 1)$, and non-labile decay rate $(\mathrm{k} 2)$ of fresh litter in bold and the differences between fresh litter parameters and 10, 48 and 180 decomposed litter DOC parameters

\begin{tabular}{|c|c|c|c|}
\hline & $\mathrm{a}$ & $\mathrm{k}_{1}$ & $\mathrm{k}_{2}$ \\
\hline Fresh & $75.7 *$ & $0.117 *$ & 0.001 \\
\hline 10 days & $7.1^{*}$ & $-0.032 *$ & $-0.002 *$ \\
\hline 48 days & $-19.7 *$ & $0.017 *$ & $0.003 *$ \\
\hline 180 days & $-28.1 *$ & 0.012 & $0.002 *$ \\
\hline
\end{tabular}

Significance is indicated by an asterisk $(\mathrm{p}<0.05)$

species V. myrtillus rates were roughly three times higher than those of the other broadleaf species. In general, the relative bioavailability of leaf derived DOC was higher than that of wood, although a consistent significant difference in lability between needle and deciduous derived leaf DOC could not be found. Litter decay progressively led to a decrease in both the amount and lability of DOC leached. In opposition of our second hypothesis, interspecific differences in leaching of DOC could not be directly explained by fresh litter $\mathrm{N}$ content, although $\mathrm{N}$ was found to be related to mass loss of the litter. Moreover, the leaching of $\mathrm{N}$ and $\mathrm{P}$ was related to DOC leaching according to power functions with exponents $>1$ for $\mathrm{N}$ and $<1$ for $\mathrm{P}$, respectively, but because these exponents were not significantly different from 1 , it should be rejected that [H2.2] nutrient leaching increased in a disproportional way to increased $\mathrm{C}$ leaching. In line with our final hypothesis, the understory vegetation was responsible for major parts of both total and labile DOC and nutrient leaching from litter at the forest stand. Most of the nutrients and DOC (total and bioavailable fractions) leached per dry litter weight came from fresh deciduous litter, in particular from the understory species V. myrtillus. Annual litterfall of the canopy outweighed understory litterfall (excluding moss biomass) and was dominated by needle litter, reflecting the species composition found in the catchment (Laudon et al. 2013). However, the relatively small proportion of annual litter produced by $V$. myrtillus was responsible for the largest share of the calculated production of water extractable DOC and nutrients coming from fresh litter, shedding new light on the key importance of the understory for biogeochemical cycling (Nilsson and Wardle 2005).

Interspecific differences in DOC leaching

Previous studies have found that mass loss of litter is related to litter $\mathrm{N}$ and lignin content (Melillo et al. 1982, 1984; Cornelissen 1996; Perez-Harguindeguy et al. 2000; Silveira 2011) and to leaf structural toughness (Perez-Harguindeguy et al. 2000). Our results partly confirm these findings as mass loss from fresh litter was positively related to $\mathrm{N}$ content, but no relationship with lignin was found. We argued that mass loss would be predictive of DOC leaching and thus also related to litter $\mathrm{N}$ content. However, although mass loss and DOC leaching was positively related, DOC leaching could not be related to litter $\mathrm{N}$ nor lignin content. Interspecific structural differences in litter could possibly explain the different leaching potentials better than litter $\mathrm{N}$ or lignin content, as we found a systematic decrease in the leaching potential between litter from deciduous leaves, needles and wood, respectively.

The DOC leaching values of $V$. myrtillus leaf litter were not only the highest of this study, but also higher than leaching rates reported for a wide range of litter sources and species in previous studies (Don and Kalbitz 2005; Hagedorn and Machwitz 2007; Wickland et al. 2007; Silveira 2011; Wymore et al. 2015). Interestingly, the $\mathrm{N}$ content and mass loss of $V$. myrtillus leaf litter were both roughly equal to that of birch, and less than that of Alnus leaf litter (Fig. 1; Supplementary Table 2), yet these two latter deciduous species yielded much lower water extractable DOC. These results are in line with previous research, where a higher water-soluble fraction was found for $V$. myrtillus in spite of relatively low litter $\mathrm{N}$ content and (1 year) mass loss as compared to a deciduous birch species (Wardle et al. 2003). The difference in leaching potential between $V$. myrtillus and other deciduous sources suggests a structural difference in litter that affects leaching, but not litter mass loss. Possibly, a higher percentage of $\mathrm{C}$ in $V$. myrtillus litter is lost through leaching and a smaller part through respiration, compared to other deciduous litter species. In practice, this would prove difficult to test as respiration on a fundamental level requires $\mathrm{C}$ to be in a soluble form to pass the cell membrane (Marschner and Kalbitz 2003). 
Hypothetically, V. myrtillus litter could have a higher affinity for microfaunal decomposition than the deciduous canopy litter, which might increase DOC leaching rates (Kalbitz et al. 2000).

\section{Litter mass loss and DOC leaching}

The DOC leaching decreased exponentially with litter mass loss, except for wood and pine litter. This is in accordance with previous research in temperate regions (Don and Kalbitz 2005; Hagedorn and Machwitz 2007). Overall it can thus be expected that DOC leaching is highest directly following litter-fall in autumn and progressively declines during the next seasons. After 180 days of litter decay, the litter sources show lower absolute leaching values and less interspecific variability, implying that species composition of the forests have profound effects during autumn senescence, but less so in the following seasons.

\section{Nutrient leaching}

Sources with high DOC leaching potentials also showed high TN and TP leaching, but we could not support our third hypothesis that the leaching of $\mathrm{N}$ and $\mathrm{P}$ increased disproportionally to increased $\mathrm{C}$ leaching. Moreover, while a previous study suggested $\mathrm{N}$ leaching to be moderately $\left(\mathrm{r}^{2}=0.36\right)$ related to litter $\mathrm{N}$ content (Schreeg et al. 2013b), this was not seen in our study. A possible explanation for the lack of this latter relationship is that the $\mathrm{N}$ leaching may show interspecific patterns (Silveira 2011), e.g. the average litter $\mathrm{N}$ soluble fraction reported is $<5 \%$, but interspecific deviations with water extractable fractions up to $>$ 25\% have been found (Schreeg et al. 2013a). While our results remain inconclusive, low DOC leaching litter sources have been found to proportionally leach more $\mathrm{P}$ than high DOC leaching litter (Wallace et al. 2008). It is likely that this difference is driven by litter $\mathrm{P}$ content, as a strong association between litter $\mathrm{P}$ content and $\mathrm{P}$ leaching $\left(\mathrm{r}^{2}=0.66\right)$ exists, with on average $26 \%$ of litter $P$ content being soluble (Schreeg et al. 2013a).

On average roughly $75 \%$ of the $\mathrm{P}$ leached was inorganic, which is less than the $90 \%$ reported for tropical species (Schreeg et al. 2013b). This suggests $P$ to be easily available for microbes. In contrast, more than half of the $\mathrm{N}$ was leached as DON, less than the
75-90\% found in other studies (Silveira 2011; Schreeg et al. 2013b). Therefore, while the leaching of $\mathrm{N}$ occurred at greater rates (Fig. 2), directly available $\mathrm{N}: \mathrm{P}$ ratios could be substantially lower than leached $\mathrm{N}: \mathrm{P}$ ratios, which is in line with previous findings in boreal lakes (Soares et al. 2016).

\section{DOC lability}

The DOC from needle and deciduous litter was more labile than wood litter DOC. However, the DOC leached from pine wood was the exception to this division and was found to be unexpectedly labile. This could be explained by the fact that the pine wood samples consisted mostly of very small branches connecting the needles to bigger branches. These branches were flexible and appeared more brittle than our other wood samples. Regarding the leaf litter sources, other comparable studies have found relatively larger interspecific differences in bioavailability of the leached DOC (Don and Kalbitz 2005; Wickland et al. 2007; Fellman et al. 2013). At the same time bioavailability in these past studies has been generally lower than in our study. While incubation periods were roughly 3 to 6 times shorter in these studies, the same dissimilarity exist when considering only the initial time phase of our DOC decay experiment. The application of different leaching protocols might explain part of the dissimilarity between the studies, as e.g. Don and Kalbitz (2005) used a pre-extraction in which litter was soaked for $24 \mathrm{~h}$ followed by a 7-day acclimatization. It could be that the more labile parts of DOC were missed because they were leached during the pre-extraction, or decomposed during the 7-day acclimatization. In our experiment, roughly $50 \%$ of the DOC would have been decomposed within 7 days. Without the highly labile DOC the differences in bio-availability of the remaining DOC would appear larger. Similarly, decomposition might have affected the DOC leached from Wickland et al. (2007), where leachates for DOC incubation were taken after a week of litter incubation in water. On the other hand, Fellman et al. reported a 2-h extraction scheme, which most likely resulted in only a very partial leaching of DOC from the litter sources. Prior to running our experiments, we tested the optimal time for leachate extraction. For our litter sources, any less than $48 \mathrm{~h}$ would result in incomplete leaching, while extending the period beyond this only slightly improves the 
returns and would inevitably lead to increased DOC loss through decomposition. In Don and Kalbitz (2005) the humification index (HIX) was strongly negatively correlated to the bioavailability of the DOC. In our study the all HIX values are below 1, indicating high bio-availability. Small differences in HIX between litter species (data not shown) might explain the small variability in bio-availability.

Litter decay initially increased lability of the DOC, followed by leaching of progressively more recalcitrant DOC. Thus, DOC to be leached from fresh litter during autumn can be deemed labile, while the DOC leached during snow melt after winter would be more recalcitrant. Lability of DOC extracted from organic horizon soils was on par with lability DOC leached from 180 days decomposed litter. This could either reflect leaching from humified litter or the selective absorption of more recalcitrant DOC to organic horizon soils (Kalbitz et al. 2005). With literature supporting high litter derived DOC adsorption in the organic layer (Hagedorn et al. 2002, 2004; Fröberg et al. 2007b, 2007a; Muller et al. 2009; Kammer and Hagedorn 2011; Guelland et al. 2013; Hagedorn et al. 2015) we would argue the latter to be a substantial part of the DOC extracted in our experiment.

The role of the understory in boreal forest DOC and nutrient dynamics

On a forest stand level, the understory was responsible for over $80 \%$ of the potentially leached DOC from fresh litter. Most of this was a result of the high DOC leaching potential of $V$. myrtillus, which in terms of litter production came third after the moss standing biomass and combined canopy production. Because water extractable DOC decreased exponentially with litter mass loss, the bulk of litter derived DOC can be expected to leach during the first months of litter decay, following the peak litterfall period in autumn.

The lack of large interspecific variation in DOC lability between litter sources and the linear relationship between nutrients and DOC leaching mean that the understory plays a substantial role in the boreal forest floor and soil biogeochemistry by not only delivering the bulk of total litter derived, but also most of the labile DOC and nutrients in autumn, when litter leaching rates are at their highest. The high lability of fresh litter leached DOC could serve as a high energy source for microbes. In soils this could be partially negated by sorption of DOC to the organic horizon, sorption is less likely to occur for labile than recalcitrant DOC (Kalbitz et al. 2005). Therefore, while most litter leached DOC in soils does not move far (Hagedorn et al. 2002, 2004, 2015; Fröberg et al. 2007b, 2007a; Muller et al. 2009; Kammer and Hagedorn 2011; Guelland et al. 2013), fresh litter labile DOC may reach depths beyond the organic horizon or at least stay in an available soluble form long enough to have a noticeable effect on soil biochemical processes. If absorbed, litter leached DOC contributes to soil organic matter buildup and may have a long-term potential for transport to further depths (Kalbitz et al. 2000; Fröberg et al. 2007b), or eventually leaching out of the soils altogether (Guggenberger and Kaiser 2003). It has been noted that mixed and coniferous stands often show higher DOC and DON concentrations in soil solution, while showing lower litter decomposition rates (Kalbitz et al. 2000); with this study we suggest that the understory could be a piece of the puzzle explaining this difference.

A subtle shift in boreal understory-canopy biomass distributions could have substantial effects on autumn $\mathrm{C}$ and nutrient cycling. Having a high understory biomass means that higher amounts of labile DOC and available nutrients are released to soils in autumn. Because V. myrtillus has such a large share in potential litter DOC leaching and is the only truly senescent understory species in our study the results presented here are limited to the Fennoscandia-and perhaps parts of the western Russian boreal forest. However, within the Fennoscandia boreal forest, the understory vegetation $V$. myrtillus is a common species among various coniferous forest classes and occur in most of the dry to wet range that divides them (Arnborg 1990). Strong north-south gradients in the boreal zone affect tree canopy density, resulting in gradients in both tree litter production as well as understory biomass. Needle litter production has been shown to be negatively correlated with both stand age and latitude (Berg et al. 1999), with a large range from 660 to $49 \mathrm{~g} \mathrm{~m}^{-2}$ year $^{-1}$ from the French Atlantic to northern Fennoscandia (Berg and Meentemeyer 2001). Understory biomass, on the other hand, increases with latitude and stand age (of pine and spruce forests)especially the biomass of $V$. myrtillus (Johansson 1995; Muukkonen and Mäkipää 2006). In light of this, the relative importance of the understory is also 
dependent on this south-north gradient. As a comparison, yearly needle litter production in our study (94.4 $\mathrm{g} \mathrm{m}^{-2}$ year $^{-1}$ ) was slightly lower, but comparable to other studies conducted at a nearby area $\sim 110 \mathrm{~g} \mathrm{~m}^{-2}$ year $^{-1}$ (Maaroufi et al. 2016) to 134-262 $\mathrm{g} \mathrm{m}^{-2}$ year $^{-1}$ (Leppälammi-Kujansuu et al. 2014) for unfertilized versus fertilized plots, or $182 \mathrm{~g} \mathrm{~m}^{-2}$ year $^{-1}$ (Ilvesniemi et al. 2009) and $75-227 \mathrm{~g} \mathrm{~m}^{-2}$ year $^{-1}$ (Bhatti and Jassal 2014) in southern Finland and Canada respectively. Maaroufi et al. (2016) reported lower birch litterfall rates compared to our estimates. Our Vaccinium biomass estimates $\left(125 \mathrm{~g} \mathrm{~m}^{-2}\right)$ are close to another study in Fennoscandia (150 to $200 \mathrm{~g} \mathrm{~m}^{-2}$ ) (Atlegrim and Sjöberg 1996) and within the range of values found in southern Finland $\left(0-210 \mathrm{~g} \mathrm{~m}^{-2}\right)$, where young forests were also included (Mäkipää 1999).

\section{Conclusion}

Our results show that the understory vegetation plays a key role in litter DOC and nutrient leaching in boreal coniferous forests. Although annual litterfall of the canopy was higher than that of the understory (excluding moss biomass), fresh deciduous litter yielded much higher amounts of total and bioavailable extractable DOC and nutrients per gram of dry litter than needle or wood litter. The leaching of $\mathrm{N}$ and $\mathrm{P}$ was proportional to DOC leaching. Consequently, with $V$. myrtillus as both the main deciduous litter source and with the highest leaching rates, the understory contributed $>80 \%$ of the litter extractable DOC and nutrients. This suggests differences in understory vegetation could have profound effects on the biogeochemistry of soils, as both energy and nutrients seem almost to be provided in proportion to the abundance of $V$. myrtillus. Although litter mass loss was strongly correlated with both DOC leaching rates and litter $\mathrm{N}$ content, interspecific differences in DOC leaching were not directly driven by litter $\mathrm{N}$ content. This further complicates our study in light of modeling coniferous boreal forest floor $\mathrm{C}$ and nutrient fluxes. The finding that one small understory species can have such an extensive effect on a forest stand scale calls for further research on $\mathrm{C}$ and nutrient leaching from common understory species and increased efforts to enhance our understanding of the understory in biogeochemical cycles.
Acknowledgements Open access funding provided by Lund University. This research was supported by Formas (\#239-2014698 \& \#2015-00049) and the Royal -Physiographic Society of Lund. The Krycklan Catchment Study is founded by VR through the SITES program, Formas, SKB, Kempe Foundation and SKB. We also want to thank Carlos Arrelano for help in the lab and Per Lofgren, Nadine Shatilla and Svenja Agathen for help in the field.

Open Access This article is licensed under a Creative Commons Attribution 4.0 International License, which permits use, sharing, adaptation, distribution and reproduction in any medium or format, as long as you give appropriate credit to the original author(s) and the source, provide a link to the Creative Commons licence, and indicate if changes were made. The images or other third party material in this article are included in the article's Creative Commons licence, unless indicated otherwise in a credit line to the material. If material is not included in the article's Creative Commons licence and your intended use is not permitted by statutory regulation or exceeds the permitted use, you will need to obtain permission directly from the copyright holder. To view a copy of this licence, visit http://creativecommons.org/licenses/by/4.0/.

Author contribution GH performed the research, analyzed the data and wrote the paper. GH and MB designed the study with help from HL. MP, IAG and QZ provided data. MB, HL, MP and IAG helped interpreting the results and contributed to the writing of the manuscript. All authors commented, edited and approved the manuscript.

\section{References}

Arnborg T (1990) Forest types of Northern Sweden: introduction to and translation of ' Det nordsvenska skogstypsschemat '. Vegetatio 90:1-13

Atlegrim O, Sjöberg K (1996) Effects of clear-cutting and single-tree selection harvests on herbivorous insect larvae feeding on bilberry (Vaccinium myrtillus) in uneven-aged boreal Picea abies forests. For Ecol Manag 87:139-148

Battin TJ, Luyssaert S, Kaplan LA, Aufdenkampe AK, Richter A, Tranvik LJ (2009) The boundless carbon cycle. Nat Geosci 2:598-600

Benscoter BW, Vitt DH (2007) Evaluating feathermoss growth: a challenge to traditional methods and implications for the boreal carbon budget. J Ecol 95:151-158

Berg B, Albrektson A, Berg MP, Cortina J, Johansson M-B, Gallardo A, Madeira M, Pausas J, Kratz W, Vallejo R, McClaugherty C (1999) Amounts of litter fall in some pine forests in a European transect, in particular Scots pine. Ann For Sci 56:625-639

Berg B, Meentemeyer V (2001) Litter fall in some European coniferous forests as dependent on climate: a synthesis. Can J For Res 31:292-301

Berggren M, Lapierre J-F, del Giorgio PA (2012) Magnitude and regulation of bacterioplankton respiratory quotient 
across freshwater environmental gradients. ISME J 6:984-993

Bhatti JS, Jassal RS (2014) Long term aboveground litterfall production in boreal jack pine (Pinus banksiana) and black spruce (Picea mariana) stands along the Boreal Forest Transect Case Study in western central Canada. Écoscience 21:301-314

Cole JJ, Prairie YT, Caraco NF, McDowell WH, Tranvik LJ, Striegl RG, Duarte CM, Kortelainen P, Downing J et al (2007) Plumbing the global carbon cycle: integrating inland waters into the terrestrial carbon budget. Ecosystems 10:171-184

Cornelissen JHC (1996) An experimental comparison of leaf decomposition rates in a wide range of temperate plant species and types. Br Ecol Soc 84:573-582

Dawson JD, Funk DT (1981) Seasonal change in foliar nitrogen concentration of Alnusglutinasa. For Sci 27:239-243

DeLuca TH, Boisvenue C (2012) Boreal forest soil carbon: distribution, function and modelling. Forestry 85:161-184

Dilly O, Zyakun A (2008) Priming effect and respiratory quotient in a forest soil amended with glucose. Geomicrobiol $\mathrm{J}$ 25:425-431

Don A, Kalbitz K (2005) Amounts and degradability of dissolved organic carbon from foliar litter at different decomposition stages. Soil Biol Biochem 37:2171-2179

Drake TW, Raymond PA, Spencer RGM (2018) Terrestrial carbon inputs to inland waters: a current synthesis of estimates and uncertainty. Limnol Oceanogr Lett 3:132-142

Fellman JB, Petrone KC, Grierson PF (2013) Leaf litter age, chemical quality, and photodegradation control the fate of leachate dissolved organic matter in a dryland river. $\mathbf{J}$ Arid Environ 89:30-37

Fröberg M, Berggren Kleja D, Hagedorn F (2007a) The contribution of fresh litter to dissolved organic carbon leached from a coniferous forest floor. Eur J Soil Sci 58:108-114

Fröberg M, Jardine PM, Hanson PJ, Swanston CW, Todd DE, Tarver JR, Garten CT (2007b) Low dissolved organic carbon input from fresh litter to deep mineral soils. Soil Sci Soc Am J 71:347-354

Guelland K, Esperschütz J, Bornhauser D, Bernasconi SM, Kretzschmar R, Hagedorn F (2013) Mineralisation and leaching of $\mathrm{C}$ from 13C labelled plant litter along an initial soil chronosequence of a glacier forefield. Soil Biol Biochem 57:237-247

Guggenberger G, Kaiser K (2003) Dissolved organic matter in soil: challenging the paradigm of sorptive preservation. Geoderma 113:293-310

Hagedorn F, Blaser P, Siegwolf R (2002) Elevated atmospheric $\mathrm{CO}_{2}$ and increased $\mathrm{N}$ deposition effects on dissolved organic carbon-clues from $\delta 13 \mathrm{C}$ signature. Soil Biol Biochem 34:355-366

Hagedorn F, Bruderhofer N, Ferrari A, Niklaus PA (2015) Tracking litter-derived dissolved organic matter along a soil chronosequence using $14 \mathrm{C}$ imaging: Biodegradation, physico-chemical retention or preferential flow ? Soil Biol Biochem 88:333-343

Hagedorn F, Machwitz M (2007) Controls on dissolved organic matter leaching from forest litter grown under elevated atmospheric $\mathrm{CO}_{2}$. Soil Biol Biochem 39:1759-1769
Hagedorn F, Saurer M, Blaser P (2004) A 13 C tracer study to identify the origin of dissolved organic carbon in forested mineral soils. Eur J Soil Sci 55:91-100

Harrison JA, Caraco N, Seitzinger SP (2005) Global patterns and sources of dissolved organic matter export to the coastal zone: results from a spatially explicit, global model. Global Biogeochem Cycles. https://doi.org/10.1029/ 2005GB002480

Hart SA, Chen HYH (2006) Understory vegetation dynamics of North American boreal forests. CRC Crit Rev Plant Sci 25:381-397

Herzog SD, Kritzberg ES (2017) Salinity Effects on Iron Speciation in Boreal River Waters. Environ Sci Technol. https://doi.org/10.1021/acs.est.7b02309c

Ilvesniemi H, Levula J, Ojansuu R, Kolari P, Kulmala L, Pumpanen J, Launiainen S, Vesala T, Nikinmaa E (2009) Long-term measurements of the carbon balance of a boreal Scots pine dominated forest ecosystem. Boreal Environ Res 14:731-753

Johansson MB (1995) The chemical-composition of needle and leaf-litter from Scots pine, Norway spruce and White birch in Scandinavian Forests. Forestry 68:49-62

Kaiser K, Guggenberger G, Haumaier L, Zech W (2001) Seasonal variations in the chemical composition of dissolved organic matter in organic forest floor layer leachates of oldgrowth Scots pine (Pinus sylvestris L.) and European beech (Fagus sylvatica L.) stands in northeastern Bavaria. Germany Biogeochem 55:103-143

Kalbitz K, Schmerwitz J, Schwesig D, Matzner E (2003) Biodegradation of soil-derived dissolved organic matter as related to its properties. Geoderma 113:273-291

Kalbitz K, Schwesig D, Rethemeyer J, Matzner E (2005) Stabilization of dissolved organic matter by sorption to the mineral soil. Soil Biol Biochem 37:1319-1331

Kalbitz K, Solinger S, Park J-H, Michalzik B, Matzner E (2000) Controls on the dynamics of dissolved organic matter in soils: a review. Soil Sci 165:277-304

Kammer A, Hagedorn F (2011) Mineralisation, leaching and stabilisation of 13C-labelled leaf and twig litter in a beech forest soil. Biogeosciences 8:2195-2208

Kolari P, Pumpanen J, Kulmala L, Ilvesniemi H, Nikinmaa E et al (2006) Forest floor vegetation plays an important role in photosynthetic production of boreal forests. For Ecol Manag 221:241-248

Laudon H, Taberman I, Ågren A, Futter M, Ottosson-Löfvenius M, Bishop K (2013) The Krycklan Catchment Study: a flagship infrastructure for hydrology, biogeochemistry, and climate research in the boreal landscape. Water Resour Res 49:7154-7158

Leppälammi-Kujansuu J, Salemaa M, Kleja DB, Linder S, Helmisaari HS (2014) Fine root turnover and litter production of Norway spruce in a long-term temperature and nutrient manipulation experiment. Plant Soil 374:73-88

Maaroufi NI, Nordin A, Palmqvist K, Gundale MJ (2016) Chronic nitrogen deposition has a minor effect on the quantity and quality of aboveground litter in a boreal forest. PLoS ONE 11:1-16

Mäkipää R (1999) Response patterns of Vaccinium myrtillus and $V$. vitis-idaea along nutrient gradients in boreal forest. J Veg Sci 10:17-26 
Marschner B, Kalbitz K (2003) Controls of bioavailability and biodegradability of dissolved organic matter in soils. Geoderma 113:211-235

Marschner B, Noble AD (2000) Chemical and biological processes leading to the neutralisation of acidity in soil incubated with litter materials. Soil Biol Biochem 32:805-813

McDowell WH (2003) Dissolved organic matter in soils: future directions and unanswered questions. Geoderma 113:179-186

Mcdowell WH, Fisher SG (1976) Autumnal processing of dissolved organic matter in a small woodland stream ecosystem, Wiley on behalf of the Ecological Society of America Stable. https://www.jstor.org/stable/1936440. REFERENCES Linked references are available on JSTOR 57:561-569

McDowell WH, Zsolnay A, Aitkenhead-Peterson JA, Gregorich EG, Jones DL, Jödemann D, Kalbitz K, Marschner B, Schwesig D (2006) A comparison of methods to determine the biodegradable dissolved organic carbon from different terrestrial sources. Soil Biol Biochem 38:1933-1942

Melillo JM, Aber JD, Muratore JF (1982) Nitrogen and lignin control of hardwood leaf litter decomposition dynamics. Ecology 63:621-626

Melillo JM, Naiman RJ, Aber JD, Linkins AE (1984) Factors controlling mass loss and nitrogen dynamics of plant litter decaying in northern streams. Bull Mar Sci 35:341-356

Meyer JL, Wallace JB (1998) Leaf litter as a source of dissolved organic carbon in streams. Ecosystems 1:240-249

Muller C, Abbasi MK, Kammann C, Clough TJ, Sherlock RR, Stevens RJ, Jäger HJ (2004) Soil respiratory quotient determined via barometric process separation combined with nitrogen-15 labeling. Soil Sci Soc Am J 68:1610-1615

Muller M, Alewell C, Hagedorn F (2009) Effective retention of litter-derived dissolved organic carbon in organic layers. Soil Biol Biochem 41:1066-1074

Muukkonen P, Mäkipää R (2006) Empirical biomass models of understorey vegetation in boreal forests according to stand and site attributes. Boreal Environ Res 11:355-369

Neff JC, Asner GP (2001) Dissolved organic carbon in terrestrial ecosystems: synthesis and a model. Ecosystems 4:29-48

Nilsson M, Sagerfors J, Buffam I, Laudon H, Eriksson T, Grelle A, Klemedtsson L, Weslien P, Lindroth A (2008) Contemporary carbon accumulation in a boreal oligotrophic minerogenic mire: a significant sink after accounting for all C-fluxes. Glob Chang Biol 14:2317-2332

Nilsson MC, Wardle DA (2005) Understory vegetation as a forest ecosystem driver: evidence from the northern Swedish boreal forest. Front Ecol Env 3:421-428

Perez-Harguindeguy N, Sandra D, Cornelissen JHC, Vendramini F, Cabido M, Castellanos A (2000) Chemistry and toughness predict leaf litter decomposition rates over a wide spectrum of functional types and taxa in central Argentina. Plant Soil 218:21-30
Preston CM, Trofymow JAT, Group CIDW (2000) Variability in litter quality and its relationship to litter decay in Canadian forests. Can J Bot 78:1269-1287

R Core Team (2016) R: a language and environment for statistical computing

Schlesinger W, Bernhardt E (2013) Biogeochemistry: an analysis of global change. Elsevier, Amsterdam

Schreeg LA, Mack MC, Turner BL (2013a) Leaf litter inputs decrease phosphate sorption in a strongly weathered tropical soil over two time scales. Biogeochemistry 113:507-524

Schreeg LA, Mack MC, Turner BL (2013b) Nutrient-specific solubility patterns of leaf litter across 41 lowland tropical woody species. Ecology 94:94-105

Silveira ML (2011) Litter decomposition and soluble carbon, nitrogen, and phosphorus release in a forest ecosystem. Open J Soil Sci 01:86-96

Soares ARA, Bergström A, Sponseller RA, Moberg JM, Giesler R, Kritzberg ES, Jansson M, Berggren M (2016) New insights on resource stoichiometry: assessing availability of carbon, nitrogen and phosphorus to bacterioplankton. Biogeosciences 14:1527-1539

Soares ARA, Kritzberg ES, Custelcean I, Berggren M (2018) Bacterioplankton responses to increased organic carbon and nutrient loading in a Boreal estuary: separate and interactive effects on growth and respiration. Microb Ecol 76:144-155

Van SJT, Stubbins A (2018) Tree-DOM : dissolved organic matter in throughfall and stemflow. Limnol Oceanogr Lett 00:00-00

Stuiver BM, Wardle DA, Gundale MJ, Nilsson MC (2014) The impact of moss species and biomass on the growth of pinus sylvestris tree seedlings at different precipitation frequencies. Forests 5:1931-1951

Wallace TA, Ganf GG, Brookes JD (2008) A comparison of phosphorus and DOC leachates from different types of leaf litter in an urban environment. Freshw Biol 53:1902-1913

Wardle DA, Nilsson M, Zackrisson O, Gallet C (2003) Determinants of litter mixing effects in a Swedish boreal forest. Soil Biol Biochem 35:827-835

Wickland KP, Neff JC, Aiken GR (2007) Dissolved organic carbon in Alaskan boreal forest: sources, chemical characteristics, and biodegradability. Ecosystems 10:1323-1340

Wymore AS, Compson ZG, Mcdowell WH, Potter JD, Hungate BA, Whitham TG, Marks JC, Wymore AS, Compson ZG, Mcdowell WH, Potter JD (2015) Leaf-litter leachate is distinct in optical properties and bioavailability to stream heterotrophs. Freshw Sci 34:857-866

Zsolnay Á (2003) Dissolved organic matter: artefacts, definitions, and functions. Geoderma 113:187-209

Publisher's Note Springer Nature remains neutral with regard to jurisdictional claims in published maps and institutional affiliations. 